University at Buffalo School of Law

Digital Commons @ University at Buffalo School of Law

$1-1-1988$

\title{
The Line Between History and Casenote
}

John Henry Schlegel

University at Buffalo School of Law

Follow this and additional works at: https://digitalcommons.law.buffalo.edu/journal_articles

Part of the Legal History Commons

\section{Recommended Citation}

John H. Schlegel, The Line Between History and Casenote, 22 Law \& Soc'y Rev. 969 (1988).

Available at: https://digitalcommons.law.buffalo.edu/journal_articles/709

(C) 1988 Law and Society Association. Reproduced with permission.

\section{IN COPYRIGHT}

This Article is brought to you for free and open access by the Faculty Scholarship at Digital Commons @ University at Buffalo School of Law. It has been accepted for inclusion in Journal Articles by an authorized administrator of Digital Commons @ University at Buffalo School of Law. For more information, please contact lawscholar@buffalo.edu. 


\title{
THE LINE BETWEEN HISTORY AND CASENOTE
}

\author{
JOHN HENRY SCHLEGEL
}

When Kermit requested that I write an essay for this Review, an ambiguity in his letter led me to inquire whether he wanted me to write about legal history written in the twentieth century or legal history written of the twentieth century. ${ }^{1}$ Unraveling that ambiguity had the queer effect of deflecting my attention from the fact that $I$ was in the process of agreeing to write about a subject that seemed to me to be close to nonexistent. To check out that perception, I sent my super-diligent research assistant out to search the relevant periodical literature published during the last fifteen years. A bit to my surprise he came back with a longer bibliography than I had expected and the observation, "I had a difficult time deciding where to draw the line between history and casenote." It seems to me that this observation just about sums up the problem and perhaps it is important to discuss that problem as we look at this largely nonexistent field in the hope that by the time there is a field there may no longer be a problem.

And just what is the problem of which I speak? I have written of it in detail elsewhere so I will limit myself to a summary (Schlegel, forthcoming). Put straightforwardly legal history is a species of intellectual history, by which I mean that the principle professional actors in the legal system-lawyers and other public officials-are intellectuals, people who do things with ideas. That leads to the problem because intellectual history as usually written is a history of ideas simpliciter and legal history, a history of legal doctrine. Thus follows my research assistant's observation. Since the standard issue casenote often provides a history of the relevant doctrine, just where is the line between legal history and the casenote?

I wish to assert that (ironically) there is a "bright line" between the two. If the job of the historian is to render the past intelligible, then the task of the legal historian is to render the legal past intelligible, a past of legal texts-not just written words, but

This essay is written for Willard Hurst who has led us all, even those who have chosen another way. Thanks are due to Fred and to the rest of the usual cast of characters, Rob and Guyora, as well as my research assistant Bruce Ikefugi.

1 This essay covers material published in the past fifteen years. I have intentionally chosen not to write about matters of legal thought and legal education because I am too close to both topics.

LAW \& SOCIETY REVIEW, Volume 22, Number 5 (1988) 
legal actions as well-and that job can only be done by rendering that text in the fullness of its context. The rationale behind this ukase is that texts are not self-defining. Words are truly arbitrary in their relationship to things and other words, and are thus understood conventionally - by convention of a group of users, the socalled hermeneutic circle. Thus, as an historical matter, a text can only be understood within the context provided by the circle of individuals for whom that text had meaning. From this follows the bright line between history and casenote, for the latter assumes that texts are self-defining, or more accurately that the relationship of text to reader is unproblematic in that all legal texts speak with an obvious voice to all legally literate readers so that there is never a need for the explicit delineation of context and at most minor, if pesky, problems of interpretation.

While most readers will understand that my ukase renders traditional doctrinal legal history problematic, (not impossible, because one can always hypothesize a context for a text and thus render that text meaningful), a moment's thought should indicate that it simultaneously renders a purely social history of law equally problematic. Social history is founded on the notion that social actions are intelligible preliterately, without the aid of words. That assertion is extremely dubious. Actions as texts are meaningful only within a context with the aid of which meaning can be constructed and that context, of necessity, must include (and here I will surely insult some member of the Association) words, for without words actions cannot be rendered, except by mimesis, much less rendered meaningful. Thus, a social history of law needs to take explicit account of the narrowly legal things, such as statutes, cases, treatises, law suits, theoretical works, however reported or made available to the relevant social actors, that made the actions meaningful. The result, in either case, is a fully socialized intellectual history.

A brief example may clarify all of this. Consider for a minute the civil rights movement. A history of the sit-in, except as either an art form or a branch of military strategy and tactics, would be nothing but a chronicle without a full understanding of the law of public accommodations as understood by the participants: the demonstrators, their leaders and their lawyers, their opponents, and the various publics at large. Simultaneously, a history of civil rights doctrine would be nothing but a casenote without fully taking into consideration the experiences of the individuals, i.e., the lawyers, leaders and demonstrators, their opponents, and the various publics, for whom these texts had, and who thus gave these texts, meaning.

Now, there are a few examples of this socialized intellectual history for the twentieth century. In a recent essay I reviewed one such book, Kalman's Legal Realism at Yale, 1927-1960 (1986). But it is basically a bad practice to set up an unknown standard and 
then to measure work done previously by that standard. So, given the limited amount of work in the field, generally, and the even more limited number of full length studies, I shall eschew the comparative game. Rather, I would like to look at an old chestnut, periodization, and then turn to particular topics.

It is surely a truism that any historical periodization is largely dependent on the purpose for which it is created. This observation, when added to the equally common one, long the staple of the social historian, that continuities always overwhelm change, generally leads sensible historians to eschew periodization debates. However, no one has ever accused me of being sensible, and only a few of being an historian, so I am going to attempt to begin a periodization dispute.

Just when does twentieth century legal history begin? The question seems so trivial, yet, I think it goes to the essence of what is understood as the twentieth century. Let me toss out four dates: $1865,1887,1898$, and 1918 . If the twentieth century is defined by the continuing, unresolved struggle over civil rights for blacks in the United States, then it began at Appomattox. If the key issue is the confrontation of the United States with nationally-effective corporate economic power, the century began sometime around the passage of the Interstate Commerce Act. If the twentieth century is about our adventure as an international political and economic power, then it begins with the Spanish-American War. And if the central problem is America's brief and inconclusive flirtation with national direction of economic and social life, than our entry into World War I is the start of the twentieth century.

Each date is defensible. The dominant social problem in this country is, and has been, at least since the civil war, race. Yes, there have been problems with immigration in general, and the immigration of Catholics and Jews in particular, and there has been a great and persistent problem with industrial labor that at its root is, I think, more social than economic. But the great issue, so great that for a long time it was taken for granted and treated as taboo, is race. The problem was raised differently in the North and South. In the North, geographic isolation was possible and allowed for informal enforcement of the underlying cultural norms, while in the South, the inability to create viable geographic isolation led to more formal systems of norms. But in both cultures, the underlying norm was subordination and was enforced by the legal system, either explicitly or simply by acting on the basis of the cultural norm. Erecting and beginning to dismantle the system of norms has taken generations of work that is yet to be completed.

The task of coping with nationally-effective corporate economic power required first that it exist. The completion of the transcontinental railroad and the admission of the last two conti- 
nental states to the union are the outer boundaries of the initial effectiveness of such power, I suppose. But the passage of the Interstate Commerce Act is a convenient starting point. At least by 1887 there was enough of a problem that we behaved as if there were a national problem, and we have done so ever since. From the creation of corporate forms sufficiently secure to allow the mobilization of European capital, to the creation of the Trust to maximize economic power; from the use of the Constitution to maximize corporate freedom, to its use to establish effective national standards of conduct; from the use of vast governmental bureaucracies to police corporate action, through the creation of pinpointed economic incentives to induce corporate action, to the creation of a tax system that can only be described as regulatory in intent, law has been at the center of the struggle over economic power in the United States. And this is a struggle that is anything but over, as financial institutions continue to lose their local character, as plant relocation and growth in white-collar jobs plays havoc with organized labor, as deregulation decreases locallyowned businesses, and as knowledge of environmental relationships turns local problems into national ones.

The role of law in the international adventures of the United States is less well known, but arguably these adventures, first creating an imperium and then acting out the assigned social role of the imperial power, are what most distinguishes any of the last ninety years of American history from its predecessors. It is a classic tar-baby story as contemporary issues demonstrate. The search for markets and resources has led to a situation where the decline in exports to those markets, enforced in an attempt to shore up lending institutions in the United States, has created a trade deficit that engulfs the entire economy. Similarly, the exercise of strategic power has created dependencies in Europe that make it impossible to disengage there and require increasing engagement elsewhere, not to mention the domestic economic crunch that would follow any serious decline in engagement such as to significantly reduce so-called defense spending. Here, beyond the obvious international norms, one must recognize the vast range of private legal devices that create and secure international economic relations. The great apparatus of national law that manages the export and import of foodstuffs and munitions, to mention only two key items, and the sheer legal ingenuity that turned an attack on a small boat into the justification for a war in which 600,000 died, or that transformed Kuwaiti tankers into American tankers so that we could defend our boats, are part of the role of law in our licit and illicit international affairs.

The assertion that the twentieth century began twenty years late is probably tough to swallow, but the notion that national direction of economic and social life of this century is the centerpiece of the legal history makes some sense. Much economic regu- 
lation takes place beginning with the Plymouth colony, but national regulation requires a nation, by definition. A government that had subsisted on customs duties and excises until the adoption of the income tax amendment in 1913 and, except for brief periods, without an effective central bank until the same time could not possibly have the pretension of claiming to be a modern regulatory state before then, and not until actual experience with an administered economy during World War II did it become plausible for Americans to think of national regulation as central to their common identity. So the late date makes sense and regulation and direction of an economy means law and lawyers.

Now, I have no stake in what choice legal historians as a class make as to when the twentieth century began. My own interests are securely within any plausible date. But it is important to note that everyone is missing the point: What is central to American law for these years . . race, the economy, international adventure, or the nation state? And, this choice will both focus research for the next generation and indicate for what neglect we will be indicted by the following generation.

All of which is not to say that I do not have a preference. I like the later date. As a pure twentieth century person, whenever I find myself on the front end of The Great War, things seem foreign. I actually think that that impression is enough to decide the question, but it also seems that the other candidates are flawed. The race issue was so successfully suppressed before World War II that, however central it is in fact, it is so peripheral in consciousness as to lead to fundamental tail and dog problems. International adventure is similar. It is so important that it masked the decline of the basic industrial might of the United States for approximately forty years after the Depression. Yet, the notion that Foggy Bottom is peripheral to America's identity, "that those furriners are little more than pesky mosquitoes," is so deep in Americans that to create a viable international issue it has to be blown completely out of proportion, as have been the Russian Bear, the ayatollah or the Sandinistas. The economy is almost the reverse; it is almost too compelling a focus. Here, I think, economic considerations lead to two stories. The first is the growth and control of a national industrial economy before the Depression. The second, starting immediately thereafter, is a relative unwillingness to control the growing technological, financial, and service economy and a shift to governmental tending of the disorderly decline of the industrial economy. This change, both in the economy and in the role of law, suggests to me an underlying shift in our understanding of things legal such as would undermine the obvious continuity. That leaves the growth of the nation state's apparatus, growth which created consciousness of the long surpressed question of race, which turned international adventurism into a big, lucrative legal business and which presided over the creation of a 
current role for government in the economy. Thus, I would focus twentieth century legal history on that theme and so what follows by the way of more detailed survey reflects that choice-to the obvious detriment of this essay.

The gentle reader who has had the patience to go this far will by now surely wonder what holds the two pieces of this essaymethod and periodization-together, especially since it is now time to discuss what I know and how much I do not know about twentieth century legal history. The connection is the lawyer, probably the key participant in the socialized intellectual history that I maintain is legal history and the key, neglected actor in legal history "of the period" to date.

I put the matter bluntly. Just what have lawyers done all day? And how has it changed? As long as these baseline questions go unanswered we shall never come close to knowing the more important why? For so-called private practice we have essentially no baseline after Daniel Webster's Boston (Konefsky, 1982), except for Bob Gordon's continuing work on corporate lawyers in the Gilded Age, which will create another island of knowledge (Gordon, 1984). But thereafter all is darkness except for Auerbach's still devastating portrait of the organized bar (1976) and some bits of biography (Auerbach, 1973; Harbaugh, 1973) until contemporary sociology takes over. Curiously, we know a bit more about the more public practices of law. From Peter Irons' work (1982) and biographies of New Deal figures such as Douglas ( $\mathrm{Si}$ mon, 1980; see also Douglas, 1974), Frank (Glennon, 1985) and Landis (Ritchie, 1980) we know a little about the more elaborate forms of government administrative practice, at least in times of relative crisis. Here the long hours, short tempers and sense of euphoria remind one of contemporary accounts of lawyers in takeover battles.

We tend to know a little bit more about lawyers' constitutional litigation, largely because of Brown $v$. Board of Education. Tushnet's work (1987) gives us a good picture of the NAACP strategy (see also Meier, 1976) and a needed sense of the chaotic nature of "grand" strategy. Elman's recent memoir (1987) and other sources (Kluger, 1975) shed some light on the federal government's activities in the case, though in all of this there is the problem of Felix Frankfurter. That problem, simply put, is that of all public lawyers' work, we know most about that of being a Supreme Court judge, and simultaneously much of what we know is highly suspect. Part of the problem is the real secrecy surrounding the institution, but a good deal of it can be attributed to Felix Frankfurter and his acolytes. As Lash's research (1975) shows, from the beginning Frankfurter wrote for his biographer and edited his papers with that in mind. Add to this the idolatry he inspired in his clerks and other associates, and his. feuding with 
Black and Douglas (Douglas's papers have clearly been severely edited with an eye to the same prize), and thus one hesitates to put trust into any document prepared by an interested party. And it is still the case that when disinterested parties discuss "the great man" (Hirsch, 1981; Murphy, 1977, 1982) they tend to get pummeled by partisans. One longs for the sense of frustrated routine that can be seen in Holmes's correspondence and instead is treated to the proposition that Black and Douglas's attempt to read the directed verdict for the defendant out of FELA is a momentous policy issue. And the print spilled on Justice Roberts' "switch in time," a matter of great import to frankfurterians, has similarly needlessly polluted our rivers and streams (see, e.g., Pusey, 1983).

Thus, in a very real sense we know more about being an appellate judge from Schick's (1970) study of the Second Circuit of the two Hands, Clark, Frank, Chase, and Swan than from all of the palaver about the Court, though here a good word should be said for the anecdotal material of the kind usually scoffed at by professionals preserved in the yearbooks of the Supreme Court Historical Society (Gossett, 1976; Knox, 1984; Stone, 1978; Taft, 1976) and the continuing effort to frame a good biography that avoids hagiography (Gal, 1980; Goldman, 1982; Schwartz, 1983; Strum, 1984; White, 1982). This is not to say that good work could not be done on the Court of Frankfurter and Douglas or on earlier courts (Bickel, 1969). We know that the two men disliked each other, just as we know that there was no 1924 picture of the Court because McReynolds refused to be photographed with Louis Brandeis, but what difference did these feuds make? My guess is that it will take much careful sifting and weighing and years of work, since the networks of affiliation extend deep into the executive and judiciary as well as academia, before we obtain any useful information.

One must honestly wonder whether or not that much effort is worthwhile. Judicial law making has its real patrician fascination, but I am sure we are much more likely to learn about the federal assumption of responsibility for economic and social policy by putting time into Joseph Cannon, Samuel Rayburn, Everett Dirksen, or Lyndon Johnson (Reedy, 1982) and their legal counselors or into the back rooms of the Department of Justice, the Securities and Exchange Commission or OPA than by studying the Court for the same amount of time. Or, consider a neglected but enormously significant piece of legislation, as Hyman has recently done (1986), for example, the Highway Act of 1958, which created the Interstate Highway System. That legislation transformed the United States. It doomed the general merchandise service of the railroads, leaving to them only bulk cargo making regular truck transport easy and cheap. And it opened up vast stretches of the continent to vacationers and more importantly to the out-migration from urban centers that has become the dominant demographic 
trend of the past decade by making "rural cities" industrially viable in national markets and personally attractive because of their newly found easy access to the big city and all its charms. Or consider how the various Higher Education Acts beginning with the National Defense Education Act of 1958 turned college education from being a requirement for the aspiring professional middle class into a requirement for the aspiring white-collar lower middle class, and how the increasing shift from grant to increasingly market-oriented loan programs has shifted student interest away from the arts, humanities, and social sciences and toward career programs. Looked at from the point of view of the Court, the one program has some impact on parkland acquisition in urban areas, (and from the perspective of litigation, generally, on urban redevelopment) and the other a more limited impact on discrimination. Those are, I suggest, fundamentally distorted understandings that would be corrected if we spent time looking at how lawyers did and did not shape those programs from their inception through implementation.

Such assumptions of federal power and concern may often have significant impacts on private practice as well. Gordon once speculated that the appearance of the Federal Estate Tax transformed a wills and trusts practice from the creation of dynastic controls to the avoidance of the tax man's bite. My related guess is that while boilerplate is still the corporate lawyer's stock and trade, the Securities Acts and the Corporate Income Tax have transformed corporate practice since the Korean War and that their failure to bite before that time is an interesting story. Here another far better known development, the constitutionalization of criminal procedure, seems likely to have had less impact on the practice of criminal law than might have been suspected, given the picture supplied by the journals and the public press. The plea bargain was already institutionalized in urban areas by 1930 and seems not to have changed much since then. What has changed is the behavior of the organs of public authority, at least a little, and the cost of real criminal defense, which is out of the reach of most citizens-except for the indigent and the successful criminal. Here, then, it is lawyers in their enactment of the routines of practice who create the meaning of these legal initiatives.

One needs to say more than a few words about legal substance, the dominant way of thinking about legal history, whatever else I may wish were the case. The Constitution, of course, bulks largest in the literature (and state policy the smallest). One significant question needs great work and has received next to none. If the significant event in twentieth century legal history is the federal assumption of the central role in setting economic and social policy, then the question I dismissed earlier, Justice Roberts' "switch," takes on more meaning. First Ackerman (1983) and now Gjerdingen (1986) argue that the events of 1937 are a moment of 
foundational politics that signal a transformation in the social and institutional arrangements of a government (see also Parrish, 1984). They have thus linked these events to the Civil War and the related constitutional amendments and to Constitution-making itself. I simply doubt that this is the case, that these events marked anything more than the temporary capitulation of an economic oligarchy. But, recent understandings of the nature of classical legal thought (Kennedy, 1980)-powers absolute within their spheres-and the nature of post realist legal thought (Katz, 1979)_balancing - that tend to support my claims about periodization, tend also to support the Ackerman-Gjerdingen claims about the events of 1937. Just what part has constitutional law played in forming the legal twentieth century?

One can play out the question in economic matters where I believe my answer is clearly correct. But in questions of civil and political rights the matter seems to me more difficult. Clearly, in some deeply perverse way, the crisis of 1937 , which signaled a retreat from the Court's interference in economic legislation (until a new conservative Court grabbed onto federalism), permitted its intervention in First Amendment questions and thus permitted imposition of national standards Congress surely would, and often did, reject. Similarly, for a time the Court was far out in front of Congress in criminal procedure, segregation, and representation. Is the Court's continued insistence on nullification of expressed public policy, state and federal, or is its action in putting these social questions within the federal domain the more important action or are the two really a part of the same thing, all branches of the federal government pulling together to create a viable nation state? I confess to having no firm answer but much curiosity unslaked by any currently available scholarship, much less the kind of scholarship that would turn the bare doctrinal history into something meaningful at some level of understanding-legislative, executive, practicing lawyer, or informed citizen.

Turning away from the constitution at such a grandiose level, a few less grand matters need to be noted. Work on civil and political rights continues (Capeci, 1986; Ely, 1976; Garrow, 1978; Lofgren, 1987; Martin, 1985; Reitman, 1975; Smith, 1986). Interestingly, we seem to be beginning to remember that there have been civil rights issues not just for Blacks, but for Asians as well for some time now (Garrott, 1983), so that a small body of work has grown on Yick Wo (Kaylor, 1983), the Japanese Exclusion cases (Irons, 1983; Yamamoto, 1986) and even General Yamashita (Guy, 1981). Similarly, the impact of the freedom of information act has begun to generate some political rights scholarship centering around the McCarthy Era loyalty programs and prosecutions (Markowitz, 1980; Schrecker, 1986), but also going back into earlier (Irons, 1984; O'Reilly, 1982; Vaughn, 1979; Williams, 1981), later (Eliffe, 1971) and contemporaneous anti-subversive schemes, such 
as the FBI's emergency detention program (Theoharis, 1978). The commerce clause, once a staple of constitutional law courses, blissfully seems to have dropped from sight, although here, I must note one would like to know what all those old tax and transportation cases were really about.

A little work is finally being done on nonconstitutional areas of federal law-making. Recent contributions have centered, as one would expect, on the various New Deal economic policies, including those relating to public works (Reeves, 1973), steel (Shaffer, 1978), oil (Brand, 1983), agriculture (Breimyer, 1983, Rassmussen, 1983), social security (Cohen, 1983), and government finance (Wallis, 1984). Clearly, more work needs to be done here centered on the shift from the corporativist solutions of the early years to the more free-market solutions of the later years and especially the second term. But, even more important is our total lack of understanding of regulation during World War II. My good friend Jim Atleson insists that mid- to late-twentieth century labor law was formed not by the NLRB (Gross, 1974) during the war but by the War Labor Board and its employees (see, Nolan, 1983). These individuals dominated the field as lawyers, arbitrators, and academics for the next thirty years. Similarly, wartime procurement surely set the pattern for federal government contracting, a bizarre and specialized subject, but one, it must be remembered, with enormous economic impact in today's economy. At the same time, federal power initiatives, TVA, Columbia Basin, Hoover Dam, and the Rural Electrifications Administration, seem to have led nowhere. Why that is so, other than the lack of effective limit on the federal borrowing power, is a puzzle, at least to me, although not, I suspect for Frug (1980), for each legal entity had the potential to be a marvelous governmental unit, neither, state or city, and not really federal either.

At the level of general economic policy there is simply nothing, and bizarrely so. We have a detailed history of the Tax Court (Dubroff, 1975, 1976, 1977a, 1977b, 1978a, 1978b, 1978c), but surprisingly little knowledge of the tax code and how it grew (Witte, 1985). Similarly, we have some knowledge of the continuing call for a federal incorporation statute (Urofsky, 1982), but little of the baseline of SEC enforcement and disclosure that has served as a queer substitute now for forty years; some knowledge of Thurman Arnold's tenure at the Anti-Trust Division (Ayer, 1971; Gressley, 1977; Miscamble, 1982), but none of anti-trust policy more generally, seen as anything other than a string of Supreme Court opinions, and such basic dimensions of economic policy as the Federal Reserve System, the Comptroller of Currency and the Treasury Department, much less such obscure initiatives as TNEC, have come to no one's attention. What we need is a good book-length history of federal economic policy broadly construed from which more specialized work might be done. 
Little is known about so-called social policy either. Some people know bits and pieces of the Works Projects Administration arts projects and even the simply wonderful state guidebooks, but little else is known of the greater projects or the parallel Civilian Conservation Corps. Did the legal form of these enterprises make any difference or would any way of distributing federal money have worked as well? Then, while we know something about unemployment (Garraty, 1986) and retirement (Graebner, 1980), although much good work is being done on labor generally (e.g., Montgomery, 1987; Tomlins, 1985) there is also Wage and Hour and Minimum Wage and Prevailing Wage legislation. Now all of this is economic regulation as well, just as is social security or worker's compensation, the staples of old-fashioned social legislation courses. Indeed, it is not until in the Eisenhower years when the nation had to construct a school desegregation policy (Bass, 1981; Belknap, 1987; Schwartz, 1986) that a largely noneconomic social issue appears (however, see Schweber, 1981). Here the peculiar structure of our federal government of limited powers may bite hard, for general social legislation, outside of the ambit of the Fourteenth Amendment or the commerce clause, is said to be impossible absent an appropriation program on which to condition it. Growth of these appropriation vehicles that covers such marvelous creations as the NSF and the NEH needs to be investigated.

The other great social policy program is environmental health and safety where interesting islands of knowledge appear (Ball, 1986; Graebner, 1976; McEvoy, 1986). Here the levers have been more diverse, essentially because many of these issues are workplace or product safety and thus more susceptible to commerce power regulation. There is, of course, a trade-off involved, or so it might seem; commerce power means economics and susceptibility to cost benefit analysis, a matter fateful to any social program because if the program were cost-effective then industry would adopt it, or so Mr. Posner would teach us. Has this difference in legal form amounted to anything as the nation's social agenda has changed? This question seems an important focus for any historian of the movement that began with meat and poultry inspection and drug licensing.

Turning away from the federal government to state and local governments and social and economic policy, what was a thin literature would have become, but for the work of Teaford $(1979,1984$, 1986), a largely nonexistent one. I doubt that this is because the states are about to become appendages of the Federal Reserve Districts or local government, the equivalent of French administrative departments. The sheer daunting nature of the task of coping with forty-eight or more jurisdictions is enough to silence any researcher. And yet, as Hurst has shown, work in even a single state can be very rewarding and often is. (Buroker, 1970; Haller, 1970; Lurie, 1972; Pisciotta, 1985). 
A careful look at state and local law-making is important because in several areas-schools, family relations and land use come immediately to mind-federal policy is still limited and may remain so, and because, as is currently being demonstrated in the area of economic development, when federal initiatives decline such governmental units end up taking in the slack. Too little significant work has been done in these areas, though note should be made of interesting discussions of the origin of the public authority (Fetner, 1977) and of the certificate of public convenience and necessity (Jones, 1979), some basic work on state policy toward municipalities in the late nineteenth and early twentieth century (Teaford, 1979, 1980) and on state legislative responses to declarations of unconstitutionality during the same years (Lindgren, 1983).

At the end of this brief trip through the twentieth century where are we? First, I have not exhaustively surveyed the literature so that all unmentioned work is to be consigned to the nether world of the casenote. Any survey of this kind is necessarily selective and this one has been explicitly so. I have ignored most work outside my chosen focus and that more than fifteen years old. I have also ignored general political history, both from political scientists and general American historians. This literature, while not directed at the legal historian's narrow concerns, often has much to offer. Second, I have not exhaustively surveyed the literature, even under my own choice as to what twentieth century legal history is or might be about. For example, nothing has been said about the one subject I know something about, legal education and legal academics. Third, I have completely ignored the available sub-themes that would deepen and enrich any portrait of the twentieth century, and there are many. Let me mention only two that are not obvious (to me at least) from my earlier depiction of possible themes.

It seems to me that at the same time that there has been the growth of a great national regulatory apparatus together with the enormous lawyerly attempt to avoid that apparatus, there has been a relatively continuous attempt to use law not in the interest of national regulation but of local exceptionalism, often paradoxically, an imitative local exceptionalism. I believe this can be seen clearly in the use of the legal tools for urban development where the emphasis is on preserving (and thus creating) the unique Buffalo, which is patterned on the unique Baltimore, which is patterned on the unique Boston. This strong countercurrent wishes to deny the national nature of the American state. Lawyers participate in this countercurrent and through their work, the doing of law, give it shape, form, and content by the use of legal words. What the relationship of this countercurrent is to arcadian themes in American culture, themes pushed in the political rhetoric of both the right 
and the left, is not obvious to me, but is at least a matter worthy of some exploration.

A second countercurrent, backwater (or what have you), is the problem of legal thought in general. Put bluntly, and here Ackerman is clearly correct, whatever the momentary stasis that legal process theory brought to legal thought in the fifties and early sixties, there has been no coherent theoretical foundation for law since the realist movement. Theorizing about law is in total chaos now and has been for approximately sixty years. That fact may be irrelevant; in one sense law seems not to mind. At the same time, that fact may be very important; how people think about their world limits, as well as creates, the possibility of legal action. Which is the case, and how we got to this state of affairs, is potentially an important, or at least interesting, topic about lawyers, legal academics, other academics, public pundits, and the ideas each uses that seems to me at least to have only a marginal relationship to the nation state and its direction of our welfare.

Other countercurrents could be identified, but it is more important to recognize a fifth limit to this exercise in review. I have not worked out in general, much less in convincing detail, the relationship between lawyers as intellectuals making things happen with words, the growth of the nation state and legal history. That is the task of the unwritten legal history of the twentieth century. Nor do I harbor any illusions that this piece will finally put the nail in the coffin of doctrinal legal history. The pull of the idea of law as rule, whatever its source or sources, is too great. Still, I am confident that if one keeps the line between history and casenote tolerably firmly in mind better legal history will be written.

JOHN HENRY SCHLEGEL is Professor of Law at the State University of New York, Buffalo School of Law. He holds a J.D. from the University of Chicago (1967).

\section{REFERENCES}

ACKERMAN, Bruce A. (1983) Reconstructing American Law. Cambridge, Mass.: Harvard University Press.

AUBERBACH, Jerold S. (1976) Unequal Justice: Lawyers and Social Change in Modern America. New York: Oxford University Press.

(1973) "Born to an Era of Insecurity: Career Patterns of Law Review Editors 1918-1941," 17 American Journal of Legal History 3.

AYER, Douglas (1971) "In Quest of Efficiency: The Ideological Journey of Thurman Arnold in the Interwar Period," 23 Stanford Law Review 1049.

BALL, Howard (1986) Justice Downwind. America's Atomic Testing Program in the 1950's, New York: Oxford University Press.

BASS, Jack (1981) Unlikely Heros. New York: Simon and Schuster.

BELKNAP, Michal R. (1987) Federal Law and Southern Order: Racial Violence and Constitutional Conflict in the Post-Brown South. Athens: University of Georgia Press. 
BICKEL, Alexander (1969) "Mr. Taft Rehabilitates the Court," 79 Yale Law Journal.

BRAND, Donald R. (1983) "Corporativism, the NRA and the Oil Industry," 98 Political Science Quarterly 99.

BREIMYER, Harold F. (1983) "Agricultural Philosophies and Policies in the New Deal," 68 Minnesota Law Review 333.

BUROKER, R.L. (1970) "From Voluntary Association to Welfare Star: The Illinois Immigrant's Protective League, 1908-1926," 58 Journal of American History 643.

CAPECI, Jr., Dominic J. (1986) “The Lynching of Cleo Wright: Federal Protection of Constitutional Rights During World War II," 72 Journal of American History 859.

COHEN, Wilbur J. (1983) "The Development of the Social Security Act of 1935: Reflections Some Fifty Years Later," 68 Minnesota Lawo Review 379.

DOUGLAS, William O. (1974) Go East, Young Man. New York: Random House.

DUBROFF, Harold (1978a) "United States Tax Court: An Historical Analysis," 42 Albany Law Review 161.

- (1978b) "United States Tax Court: An Historical Analysis," 42 Albany Law Review 191.

(1978c) "United States Tax Court: An Historical Analysis," 42 Albany Law Review 353.

- (1977a) "United States Tax Court: An Historical Analysis," 41 Albany Law Review 1.

- (1977b) "United States Tax Court: An Historical Analysis," 41 Albany Law Review 639.

- (1976) "United States Tax Court: An Historical Analysis," 40 Albany Law Review 253.

- (1975) "United States Tax Court: An Historical Analysis," 40 Albany Law Review 7.

ELIFFE, John T. (1971) Crime, Dissent and the Attorney General: The Justice Department in the 1960's. Beverly Hills: Sage Publications.

ELMAN, Philip (1987) "The Solicitor General's Office, Justice Frankfurter, and Civil Rights Litigation, 1946-1960: An Oral History," 100 Harvard Law Review 817.

ELY, James (1976) The Crisis of Conservative Virginia: The Byrd Organization and the Politics of Massive Resistance. Knoxville: University of Tennessee Press.

FETNER, Gerald (1977) "Public Power and Professional Responsibility: Julius Henry Cohen and the Origin of the Public Authority," 21 American Journal of Legal History 15.

FRUG, Gerald E. (1980) "The City as a Legal Concept," 93 Harvard Law Review 1057.

GAL, Allon (1980) Brandeis of Boston. Cambridge, MA: Harvard University Press.

GARRATY, John Arthur (1986) The Great Depression: An Inquiry into the Causes, Course and Consequences of the Worldwide Depression of the Nineteen-Thirties, as Seen by Contemporaries and in the Light of History. San Diego: Harcourt, Brace, Jovanovich.

GARROTT, M. Browning (1983) "Prejudice Goes to Court: The Japanese and the Supreme Court in the 1920's," 62 California History 122.

GARROW, David J. (1978) Protest at Selma: Martin Luther King, Jr. and the Voting Rights Act of 1965. New Haven: Yale University Press.

GJERDINGEN, Donald (1986) "The Future of Legal Scholarship and the Search for a Modern Theory of Law," 35 Buffalo Law Review 381.

GLENNON, Robert J. (1985) The Iconoclast as Reformer: Jerome Frank's Impact on American Law. Ithaca: Cornell University Press.

GOLDMAN, Eliot (1982) "Justice William O. Douglas: The 1944 Vice Presidential Nomination and His Relationship with Roosevelt, an Historical Perspective," 12 Presidential Studies Quarterly 377.

GORDON, Robert W. (1984) "The Ideal and the Actual in Law: Fantasies and Practices of New York City Lawyers, 1870-1910," in Gerard W. Gawalt (ed.) The New High Priests: Lawyers in Past Civil War America. Westport, Conn.: Greenwood Press. 
GOSSETT, E.H. (1976) "My Father the Chief Justice," Yearbook of the Supreme Court Historical Society.

GRAEBNER, William (1980) A History of Retirement: The Meaning and Function of an American Institution, 1885-1978. New Haven: Yale University Press.

(1976) Coal Mining Safety in the Progressive Period: The Political Economy of Reform. Lexington: University Press of Kentucky.

GRESSLEY, Eugene (1977) Voltaire and the Cowboy. Boulder: Colorado Associated University Press.

GROSS, James A. (1974) The Making of the National Labor Relations Board: A Study in Economics, Politics and the Law. Albany: State University of New York Press.

GUY, G.F. (1981) "The Defense of General Yamashita," Yearbook of the Supreme Court Historical Society.

HALLER, M.H. (1970) "Urban Crime and Criminal Justice: The Chicago Case," 57 Journal of American History 619.

HARBAUGH, William H. (1973) Lawyer's Lawyer: The Life of John Davis. New York: Oxford University Press.

HIRSCH, Harry N. (1981). The Enigma of Felix Frankfurter. New York: Basic Books.

HYMAN, Harold (1986) American Singularity. Athens: University of Georgia Press.

IRONS, Peter (1984) "Politics and Principle: An Assessment of the Roosevelt Record on Civil Rights and Liberties," 59 Washington Law Review 693.

(1983) Justice at War. New York: Oxford University Press.

- (1982) New Deal Lawyers. Princeton: Princeton University Press.

JONES, William K. (1979) "Origins of the Certificate of Public Convenience and Necessity: Developments in the States 1870-1920," 79 Columbia Law Reviero 426.

KALMAN, Laura (1986) Legal Realism at Yale, 1927-1960. Chapel Hill: University of North Carolina Press.

KATZ, Al (1979) "Studies in Boundary Theory: Three Essays in Adjudication and Politics," 28 Buffalo Law Review 383.

KAYLOR, Dan (1983) "Orders that Wouldn't Wash: Historical Background of Yick Wo v. Hopkins," 11 Lincoln Law Review 205.

KENNEDY, Duncan (1980) "Toward an Historical Understanding of Legal Consciousness," 3 Research in Law and Sociology.

KLUGER, Richard (1975) Simple Justice: The History of Brown v. Board of Education and Black America's Struggle for Equality. New York: Knopf.

KNOX J. (1984) "Some Comments on Chief Justice Hughes," Yearbook of the Supreme Court Historical Society.

KONEFSKY, Alfred (ed.) (1982) The Legal Papers of Daniel Webster, Vol. 1. Hannover: University Press of New England.

LASH, Joseph (1975) From the Diaries of Felix Frankfurter. New York: Norton.

LINDGREN, Janet (1983) "Beyond Cases: Reconsidering Judicial Review," Wisconsin Law Review 583.

LOFGREN, Charles A. (1987) The Plessy Case: A Legal-Historical Interpretation. New York: Oxford University Press.

LURIE, Jonathan (1972) "Private Associations, Internal Regulation and Progressivism: The Chicago Board of Trade 1880-1923 as a Case Study," 16 American Journal of Legal History 215.

McEVOY, Arthur (1986) The Fisherman's Problem: Ecology and the Law in the California Fisheries 1850-1980. Cambridge: Cambridge University Press.

MARKOWITZ, Gerald E. (1980) 'The 'Crime of the Century' Revisited: David Greenglass' Scientific Evidence in the Rosenberg Case," 44 Science and Society 1.

MARTIN, Charles H. (1985) "Race, Gender and Southern Justice: The Rosalee Ingram Case," 29 American Journal of Legal History 251.

MEIER, August (1976) "Attorneys Black and White: A Case Study of Race Relations within the NAACP," 62 Journal of American History 913.

MISCAMBLE, W.D. (1982) "Thurman Arnold Goes to Washington: A Look at Antitrust Policy in the Later New Deal," 61 Business History Review 1. 
MONTGOMERY, David (1987) The Fall of the House of Labor: The Workplace, the State and American Labor Activism 1865-1925. New York: Cambridge University Press.

MURPHY, Bruce Allen (1982) The Brandeis ${ }^{\circledR}$ Frankfurter Connection: The Secret Political Activities of Two Supreme Court Justices. New York: Oxford University Press.

- (1977) "A Supreme Court Justice as Politicians: Felix Frankfurter and Federal Court Appointments," 21 American Journal of Legal History 316.

NOLAN, Dennis R. (1983) "American Labor Arbitration: The Maturing Years," 35 Florida Law Review 558.

O'REILLY, Kenneth (1982) "A New Deal for the FBI: The Roosevelt Administration, Crime Control and National Security," 69 Journal of American History 638.

PARRISH, M.E. (1984) "The Great Depression, the New Deal, and the American Legal Order," 59 Washington Law Review 723.

PISCIOTTA, Alexander W. (1985) "Treatment on Trial: The Rhetoric and Reality of the New York House of Refuge, 1857-1935," 29 American Journal of Legal History 151.

PUSEY, M.J. (1983) "Justice Roberts' 1937 Turnaround," Yearbook of the Supreme Court Historical Society 103.

RASSMUSSEN, Wayne D. (1983) "New Deal Agricultural Policies after Fifty Years," 68 Minnesota Law Review 353.

REEDY, George (1982) "The True Dawn of Civil Rights," 14(3) Washington Monthly 46.

REEVES, William D. (1973) "The PWA and Competitive Administration in the New Deal," 60 Journal of American History 357.

REITMAN, Alan (ed.), (1975) The Pulse of Freedom: American Civil Liberties: 1920-1970. New York: Norton.

RITCHIE, Donald (1980) James M. Landis. Cambridge, Mass.: Harvard University Press.

SCHICK, Marvin (1970) Learned Hand's Court. Baltimore: Johns Hopkins University Press.

SCHLEGEL, John Henry (forthcoming) "The Ten Thousand Dollar Question," Stanford Law Review.

SCHRECKER, Ellen (1986) No Ivory Tower: McCarthyism and the Universities. New York: Oxford University Press.

SCHWARTZ, Bernard (1986) Swann's Way: The School Busing Case and the Supreme Court. New York: Oxford University Press.

(1983) Super Chief: Earl Warren and His Supreme Court. New York: New York University Press.

SCHWEBER, Claudine (1981) "Criminalization and Incarceration: The Federal Response to Drug Addiction among Women, 1914-1934," 4 George Mason University Law Review 71.

SHAFFER, B.D. (1978) "Responses to Competition in the Steel Industry 1918-1935," 32 Southwestern University Law Review 835.

SIMON, James F. (1980) Independent Journey: The Life of William O. Douglas. New York: Harper \& Row.

SMITH, Donald L. (1986) Zechariah Chaffee Jr., Defender of Liberty and Law. Cambridge, Mass.: Harvard University Press.

STONE, L.H. (1978) "My Father the Chief Justice," Yearbook of the Supreme Court Historical Society.

STRUM, Philippa (1984) Louis D. Brandeis: Justice for the People. Cambridge, Mass.: Harvard University Press.

TAFT, C.P. (1976) "William Howard Taft, My Father the Chief Justice," Yearbook of the Supreme Court Historical Society.

TEAFORD, John C. (1986) The Twentieth Century American City: Problem, Promise and Reality. Baltimore: Johns Hopkins University Press. (1984) The Unheralded Triumph: City Government in America, 1870-1900. Baltimore: Johns Hopkins University Press.

(1980) "State Administrative Agencies and the Cities 1890-1920," 25 American Journal of Legal History 225.

(1979a) "Special Legislation and the Cities 1865-1900," 23 American Journal of Legal History 189. 
(1979b) City and Suburb: The Political Fragmentation of Metropolitan America. Baltimore: Johns Hopkins University Press.

THEOHARIS, A. (1978) "The Truman Administration and the Decline of Civil Liberties: The FBI's Success in Securing Authorization for a Preventative Detention Program" 64 Journal of American History 1010.

TOMLINS, Christopher (1985) The State and the Unions: Labor Relations, Law and the Organized Labor Movement in America, 1880-1960. Cam. bridge, Mass.: Harvard University Press.

TUSHNET, Mark (1987) The NAACP's Legal Strategy against Segregated Education, 1925-1950. Chapel Hill: University of North Carolina Press.

UROFSKY, Melvin I. (1982) "Proposed Federal Incorporation in the Progressive Era," 26 American Journal of Legal History 160.

VAUGHN, Stephen (1979) "First Amendment Liberties and the Committee on Public Information," 23 American Journal of Legal History 95.

WALLIS, John Joseph (1984) "The Birth of the Old Federalism: Financing the New Deal 1932-1940," 44 Journal of Economic History 139.

WHITE, G. Edward (1982) Earl Warren, a Public Life. New York: Oxford University Press.

WILLIAMS, David (1981) "The Bureau of Investigation and its Critics, 1918-1921: The Origins of Federal Political Surveillance," 68 Journal of American History 560.

WITTE, John F. (1985) The Politics and Development of the Federal Income Tax. Madison: University of Wisconsin Press.

YAMAMOTO, Erick (1986) "Korematsu Revisited-Correcting the Injustice of Extraordinary Government Excess and Lax Judicial Review," 26 Santa Clara Law Review 1.

\section{CASE CITED}

Brown v. Board of Education, 349 U.S. 294 (1954). 
